A 108

\title{
電場による粒子挙動の可視化
}

\author{
押井 和毅 (日本大学)，崔 題恩（日本大学） \\ 小原 弘道 (首都大学東京), 武居 昌宏 (日本大学) \\ Movement of micro particles under electrical Field
}

Kazuki OsHII, Je-Eun Choi, Hiromichi OBara, Masahiro TAKEI

\begin{abstract}
A Microchannel is very essential in studying the chemical reactions and downsizing of the particles in a particular system. To fabricate microchannel devices, thorough understanding of the diffusion reactions inside the microchannel from the viewpoint of multiphase flow dynamics is needed. In measuring the resistance, it is necessary to consider the electric field caused by the electrodes and the force distribution inside the particles. Because of a non-uniform electric field distribution inside the system, the forces inside the particles are not equal.
\end{abstract}

Keywords :Micro channel, Micro field, Multi phase flow, Micro particle, electrical field

\section{1. 粕詇}

現在, 社会の様々な分野でダウンサイジングが進んで おり，中でもマイクロチャンネルによって提供されるミ ク口な反応場は化学反応そのものに影響を与える可能性 を秘めている.マイクロチャンネルの応用䉏囲は広く、医 療や機器, 科学などその用途哕多岐にわたり,マイクロチ ヤンネルは大きさを変えずに数を增やすことにより生産 量を増大させるため, 実験室での合成から工業的な生産 への移行が格段に効率的に行えると期待されている.こ れらのためには，マイクロチャンネル内での粒子の分離 や分級などの操作技術の確立が必要不可欠である. 光や 電場(1)などによる研究が進められてはいるものの、、 イクロ頜域での粒子操作に関する技術俚十分に確立され ていない.

本研究ではマイクロチャンネル内での電場による粒子 操作技術を確立するために、初めに基䊙研究とし，简単な 実駼装置を作成し、電場强度・周波数を変化させること で装置内の粒子挙動を計測し, 粒子の分離, 分級に向けた 知見を得ることを目的としている.

\section{2. 理侖}

粒子の分離, 分級するために誘電泳動に注目する.ここ で球形粒子に偟く誘電泳動力 $F_{\text {dep }}$ は実效值 $E$, 角周波数 $\omega$, 粒子の半径 $r$ とすると

$$
F_{\text {dep }}=2 \pi r^{3} \varepsilon_{m} \operatorname{Re}[K(\omega)] \nabla E^{2}
$$

となる.また, $\mathrm{K}(\omega)$ は Clausius-Mossotti factor といい,

$$
K(\omega)=\left(\varepsilon_{p}{ }^{*}-\varepsilon_{m}{ }^{*}\right) /\left(\varepsilon_{p}{ }^{*}+2 \varepsilon_{m}{ }^{*}\right)
$$

と表される. $\mathcal{E}_{p} ; \mathcal{E}_{m}$ 忙誘電率と導電率並びに角周波数か ら導出される粒子および媒質の複素誘電率である.式(1) において $\operatorname{Re}[K(\omega)]=0$ では粒子に力が作用せず，
$\operatorname{Re}[K(\omega)]>0$ であれば正の誘電泳動. $\operatorname{Re}[K(\omega)]<0$ であれば 負の誘電泳動となる(2).

\section{3. 実験}

Fig.1 に作成したマイクロチャンネルを示寸.チャンネ ルは粒子操作のための電極アレイを有しており，流路部 分は高さ $1 \mathrm{~mm}$, 流路幅 $1 \mathrm{~mm}$, 長さ $38 \mathrm{~mm}$ である.粒子 (Duke, ポリスチレン) は脱イオン水に分橵させ、流路に 注入し、実験を和こなった. Fig.2に実駼装置を示す，実験 ではファンクションジェネレータにより電圧と周波数を 変化させ交流電場を電極間に形成した。なお、本実験では 対向して配置された 1 対の電極間にのみ電場を形成した 粒子の動きは顕微鏡に接続した CCD カメラでコンピュー 夕に画像として取得した. 取得した画像より粒子の動き の観察, 画像解析を行い、速度情報を取得した: 実験条件 は, 粒子は直径 $d=1.3 \mathrm{\mu m}-2.0 \mathrm{\mu m}$ とした.また, 電圧は $V$ $=1.5 \mathrm{~V}$ とし, 周波数 $f=1 \mathrm{~K}, 10 \mathrm{~K}, 100 \mathrm{~K}, 1 \mathrm{MHz}$ の 4 パターン とした.

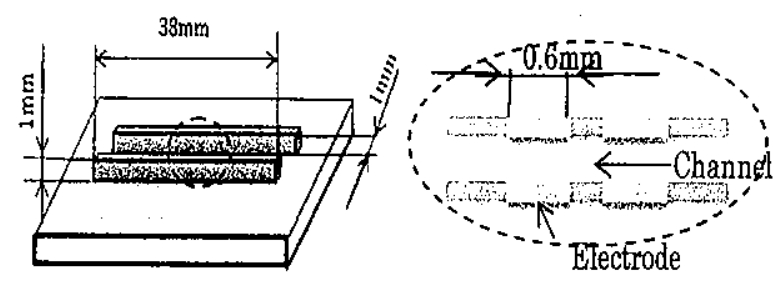

Fig. 1 Micro channel

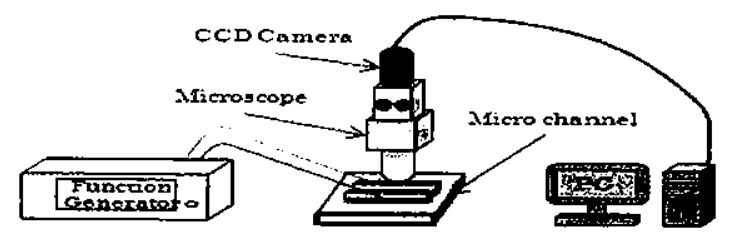

Fig. 2 Experimental device 


\section{4. 結果}

実験より得られた粒子挙動ならびに, 画像解析により得 られた速度特性を以下に示す。

Fig. 3 は $d^{2}=1.3 \mu \mathrm{m}, E=1 \mathrm{~V} / \mathrm{mm}, f=100 \mathrm{kHz}$ における電極近 傍の粒子举動を時系列に示したものである. 画像のコン トラストを調整し示している.右側の黒い部分は電極で あり， $t$ は電場印加後から時間である。ここで，矢印に示 す $2 つ の$ 粒子に着目すると，時間経過とともに相互の粒 子の位置関係を保ちながら粒子は右側から左倒にほぼ平 行に移動する，なお、他の粒子も同様にほぼ平行に移動 し, これらの粒子の举動は，その強弱性あるものの，い ずれの電場強度、周波数ならびに粒子径においても，同 様である。
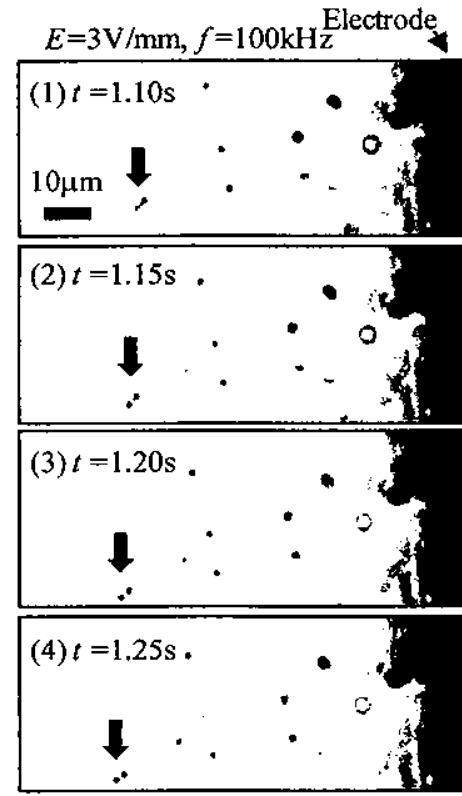

Fig.3 Movement of particles near electrode $(\alpha=1.3 \mu \mathrm{m})$

Fig.4は各周波数条件における粒子の移動速度を電場強 度により整理した図である.代表として, 粒子直径 $1.3 \mu \mathrm{m}$ の結果を示寸，電場強度の增加にともない，粒子の移勘 速度は增大する。いずれの周波数においても周波数によ らずほぼ同様の粒子の移動速度となっている。

ただし， $1 \mathrm{KHz}$ に関しては他に比べ，その変化が小さく なっている.

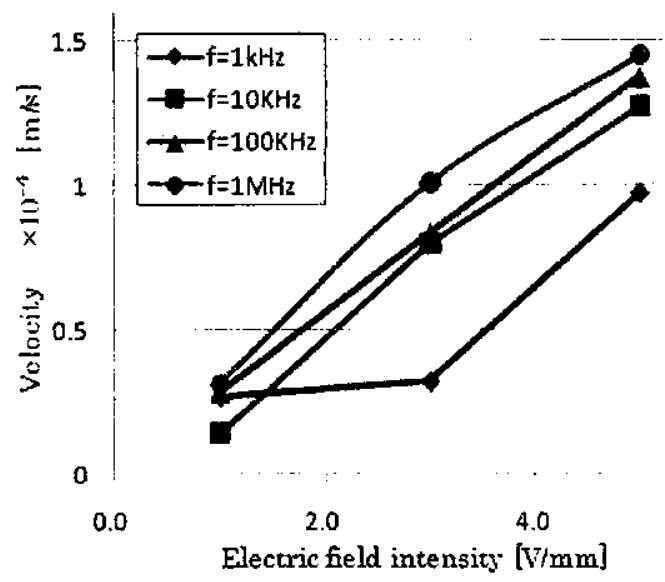

Fig.4 Particle Velocity under AC electric field

\section{5. 考察}

Fig.3において粒子挙動は, 電極に近い領域でほぼ平行 に左側に移動する結果が得られたが，流路中央付近では 粒子が上下に動いたり，前方の粒子の移動速度に差異が 現れるなどの動きが観察された。このことは，電極部近 傍に形成される,三次元的な電場によって，局所的に電場 勾配が形成されているためではないかと考えられ，公配 が異なる領域が計測面内に存在することで粒子に作用す る誘電泳動力 $F_{d e p}$ に差異が現れたためと考えられる.

Fig.4 より電場強度 $E$ に対応して速度 $v$ は増大している が，理論から考えられる式(1)での電場強度 $E^{2}$ の変化は 計測されなかった。このことに関しては, 前述した三次 元的な電場勾配の影響や計測の精度も含めいくつかの要 因が考えられる，例えば，粒子の移動速度の増加に伴っ て，抗力が增大することで $F_{\text {dep }}$ は増加しているにも関わ らず，電場強度 $E^{2}$ の影響が表れなかったと考えられる。 また，前述で示したように三次元的な電場勾配の影響も 考えられる.また， $f=1 \mathrm{kH}$ が他の周波数条件に比し，小 さい速度を示したことは，より小さい周波数条件で, $F_{d p p}=0$ を示す $K(\omega)=0$ となる条件が存在することを示唆 している. なお，計測の精度として本報告では基礎的評 価として，粒子挙動を代表するいくつかの粒子に着目し， 粒子移動距䧄隹をもとに速度算出をおこなっている. 今後, 詳細な議論のためには計測領域を分割するなど局所的な 速度評価も含め, 統計的な粒子挙動評牺が必要である。

ここでは紙面の都合上，図示はしていないが，粒子径 変化による粒子の移動速度変化の結果から $1.3 \mu \mathrm{m} に$ に比し

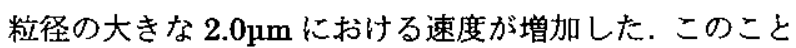
から, 式(1)における粒子の半径 $r$ の 3 乗項としての大き い影響を及ぼしていると考えられ，本実験での電場印加 による粒子の挙動は誘電泳動力 $F_{\text {dop }}$ が支配的な役割を果 たしていると考えることができる。

\section{6. 結諭}

マイクロチャンネル内での粒子の分級・分離を目的にし, 基礎的な知見を得るために粒子を観察を行った.

電場強度が增加するにともない粒子の移動速度む增加 し，各周波数においても同様の粒子の移動速度となり， 誘電泳動が支配的であることが明らかになった。今後, 粒子径 $d$, 電場強度 $E$, また, 周波数 $f か ゙$ 粒子の挙動への 影響を評価が必要である.

\section{参 考文 献}

1）たとえば，小原ほか:ナノ加工のための電場誘起マイクロジ エット形成特性, 日本機械学会関東支部講演会, No.090-01(2009) pp.455-456.

2）觜津正夫：綉電泳動による生体分子のハンドリング技術と分 離分析人の忘用，電子情報通信学会踚文誌,Vol.J83-C, No.1(2000) pp.1-8. 